safe rule, and that is not to drive after drinking, for no level of alcohol in the blood can be detected below which most people's performance in tests is unimpaired. ${ }^{1}$ But knowing that it would be unrealistic to prohibit from driving everyone who has recently had a drink the committee has given the level of $50 \mathrm{mg} . / 100 \mathrm{ml}$. as " the highest that can be accepted as consistent with the safety of other road users." What now of the $80-\mathrm{mg}$. level ? The proposal is that anyone who drives with that concentration of alcohol in his blood shall be deemed to have committed an offence at law. No other evidence need be adduced to show that he has acted illegally. But at lower levels of alcohol in the blood a driver may still be convicted of driving "under the influence," and in those circumstances evidence would be adduced, as at present, on his state of health, intoxication, and so on. Thus the $80 \mathrm{mg} . / 100 \mathrm{ml}$. is like the 30 m.p.h. speed limit: merely to exceed it would be to break the law. And just as speeds well below 30 m.p.h. may be unsafe in some circumstances so may levels of blood alcohol well below 80 or $50 \mathrm{mg}$. per $100 \mathrm{ml}$.

Whether $80 \mathrm{mg} . / 100 \mathrm{ml}$. is the best level to choose for this purpose will no doubt be debated. The committee arrived at it after studying much evidence on the effects of alcohol on performance. Some of this was reviewed recently in these columns, ${ }^{2}$ and a highly informative study has been carried out at Grand Rapids, Michigan. ${ }^{3}$ This showed among other things that the type of men least likely to be involved in a motor accident are those who have had most education, hold good jobs, and are middle-aged. But blood-alcohol levels of $80 \mathrm{mg} . / 100 \mathrm{ml}$. and upwards rapidly flatten out differences of that kind. In proposing a change in the law the committee had also to consider public opinion, recommending a level that would command general assent. Critics who think it is set too high may be surprised to know that people are at present being certified as fit to drive despite blood levels of alcohol between 100 and $150 \mathrm{mg} . / 100 \mathrm{ml}^{4}$ Those who think 80 is too low may note from its earlier report that the committee was impressed "by the evidence of the rapidity with which driving ability deteriorates, even in the most hardened drinkers and in the most experienced drivers, at concentrations of alcohol in the blood in excess of $100 \mathrm{mg} . / 100 \mathrm{ml}$."

\section{Laboratory Diagnosis of Rubella}

Clinical diagnosis of rubella is often difficult even in an epidemic. A recent report by S. E. J. Young and A. M. Ramsay $^{1}$ emphasizes the important diagnostic criteria in rubella; even using these they found that rubella was suspected wrongly in 179 out of 434 cases. Since the reports of the isolation of rubella virus by tissue-culture techniques were published in $1962^{2-4}$ much progress has been made in the diagnosis of rubella both by isolation of the virus and by serology. T. H. Weller and F. A. $\mathrm{Neva}^{2}$ first isolated the virus from the blood and urine of patients with rubella by inoculation of primary cultures of human amnion or embryonic skin muscle. The presence of virus was recognized by degenerative changes in the cell sheets, but these changes developed very slowly. Simultaneously, P. D. Parkman and his associates, ${ }^{3}$ and others ${ }^{4}$ recovered virus from nasopharyngeal washings by inoculation of primary cultures of the kidney cells of the African green (vervet) monkey. Another method for the isolation of rubella virus was recently described by K. McCarthy and his colleagues. ${ }^{5}$ They showed that the virus multiplied in a transformed line of rabbit-kidney cells, the RK13 line, producing cytopathic changes which could be detected by phase-contrast microscopy. Later J. A. Dudgeon, N. R. Butler, and S. A. Plotkin showed that on passage in RK13 cells rubella virus produced specific cytopathic changes which could be seen on ordinary light microscopy. Once the virus had been isolated it became possible to develop serological tests for estimation of rubella antibody. ${ }^{2-5} 7$ The progress made in the development of these laboratory tests in the past two years is striking in view of the technical difficulties involved. It was clear from papers presented at a recent seminar on measles and rubella, held in Paris, ${ }^{8}$ that already much is known about such aspects of rubella as the morphology of the virus, its growth requirements and nucleic-acid content, diagnostic procedures, epidemiological features, and immunological aspects of foetal rubella.

The practical value of virus studies in rubella in pregnancy has recently been demonstrated by S. A. Plotkin. ${ }^{9}$ Virus was readily isolated from uncomplicated cases of rubella, but nasal swabs were often found to be positive when the corresponding throat swab was negative. The diagnosis of rubella was also confirmed in three cases of thrombocytopenic purpura after rubella and in several cases of typical rubella in pregnancy. The diagnosis of rubella was also confirmed in four out of five pregnant women with illnesses not typical of rubella. In these cases the rash was atypical in character and distribution, and there was little or no fever or lymphadenopathy. Surprisingly, confirmation was also possible even when patients were seen after the acute phase of the illness. These results show that throat swabs may be positive for as long as a week after the onset of the rash; this is in keeping with the recent observations by $\mathrm{R}$. H. Green and his associates $^{10}$ on the pathogenesis of rubella. Plotkin found that in one or two instances an increase in antibody could still be detected as late as two weeks after the rash ; generally speaking, however, it is advisable to collect the first specimen of serum within two to three days of the onset of the rash.

These procedures (especially virus isolation because it is quicker) are now useful aids in the diagnosis of rubellaparticularly in pregnancy because of the risk of damage to the foetus by rubella virus. Thus it is now possible to identify rubella virus in sporadic cases or in an outbreak, and it may

1 Young, S. E. J., and Ramsay, A. M., Brit. med. F., 1963, 2, 1295. Weller, T. H., and Neva, F. A., Proc. Soc. Exp. Biol. (N.Y.), 1962, 111, 215 3 Parkman, P. D., Buescher, E. L., and Artenstein, M. S., ibid., 1962, 111,
225.

Sigurdardottir, B., Givan, K. F., Rozee, K. R., and Rhodes, A. J., Canad. med. Ass. F., 1963, 88, 128.

McCarthy, K., Taylor-Robinson, C. H., and Pillinger, S. E., Lancet, 1963, 2, 593.

- Dudgeon, J. A., Butler, N. R., and Plotkin, S. A., Brit. med. F., 1964, 2, 155.

'Sever, J. L., Schiff, G. M., and Traub, R. G., F. Amer. med. Ass., 1962 , 182, 663.

Report of Proceedings of a Seminar on Measles and Rubella at Centre Internationale de l'Enfance, Paris. June 1964. Arch. Virusforsch. In the press.

- Plotkin, S. A., F. Amer. med. Ass., 1964, 190, 265.

Green, R. H., Balsamo, M. R., Giles, J. P., Krugman, S., and Mirick, G. S., Trans. Ass. Amer. Phycns, 1964, 77. ${ }^{11}$ Krugman, S., and Ward, R., in Infectious Diseases of Children, 1964,

18 McDonald, J. C., Brit. med. F., 1963, 2, 416.

13 Plotkin, S. A., Dudgeon, J. A., and Ramsay, A. M., ibid., 1963, 2, 1296.

14 Weller, T. H., Alford, C. A., and Neva, F. A., New Engl. F. Med., 1964 270, 1039 Kay, H. E. M., Peppercorn, M. E., Porterfield, J. S., McCarthy, K., and

Alford, C. A., Neva, F. A., and Weller, T. H., New Engl. F. Med., 1964,
271, 1275 . 
be possible to treat women exposed to infection early in pregnancy. Recently some workers have doubted whether immune globulin can prevent rubella in pregnancy, ${ }^{11}$ and in view of new information on the long period of infectiousness of rubella, ${ }^{10}$ both before and after the rash, this is not altogether surprising. However, until some form of active immunization can be developed, passive immunization with immune globulin is the only method of prophylaxis, and trials in Britain ${ }^{12}$ have shown that it may be effective.

In a preliminary report S. A. Plotkin, J. A. Dudgeon, and A. M. Ramsay ${ }^{13}$ showed that several children with the rubella syndrome had high levels of circulating antibody. They considered that immunological tolerance did not develop as a result of intrauterine infection. These observations have now been confirmed, ${ }^{6}{ }^{14}$ and it appears that the presence of rubella antibody in infants aged 6 months to 1 year (by which time maternal antibody would normally have disappeared) probably indicates an acquired immunity after foetal infection. It has been postulated that antibody is produced by the foetus rather than post-natally, ${ }^{6}{ }^{14}$ and the findings of H. E. M. Kay and his associates point to a possible mechanism for this unusual immunological response. ${ }^{15}$ They isolated rubella virus from a human foetus removed by hysterectomy 23 weeks after the last menstrual period in a woman with a history of rubella at the fifth week. Other workers have made similar isolations, but in this case rubella virus persisted in the foetal tissues for some four and a half months after infection. Persistence of virus appears to be a common feature following rubella infection of the foetus, for C. A. Alford and his colleagues ${ }^{16}$ isolated virus regularly from both placenta and foetus removed from women as long as five to six weeks after onset of the rash. Virus was also isolated from the nasopharynx and urine from four infants with the rubella syndrome for several weeks after birth. Thus rubella virus can persist for very long periods, the length of which probably depends on the stage in pregnancy at which infection first takes place. If virus can persist for this length of time then presumably this can lead to an active immune response at a later stage in pregnancy. Whether infection in these children with congenital rubella is ever eliminated, and by what mechanism, has yet to be determined.

\section{Training of Radiographers}

Proposals by the Society of Radiographers to increase the training period of radiographers from two years to three have for several months been discussed in our correspondence columns-and in $x$-ray departments up and down the country. What should a radiographer know ? The following questions from recent examination papers are pertinent:

" A biopsy of a skin lesion is taken in the department; what procedure should be followed before the specimen is sent to the laboratory ?"

"What is lymphatic leukaemia, and how is it treated ?"

"Describe one type of image intensifier, illustrating with a simple diagram its main features."

"Write brief notes on the photographic uses of the following:(a) silver bromide, (b) potassium bromide. . . ."

"The attenuation (absorption) of monochromatic $x$-radiation is stated to be exponential. Explain the meaning of the terms 'monochromatic' and 'exponential." "'

"Why is the presence of dust dangerous in hospitals?"
Evidently a wide range of knowledge is expected, even on matters which might be thought the preserve of the physician, engineer, physicist, administrator, or laboratory technician. The present curriculum calls for initial qualifications including four or five " $\mathrm{O}$ "-level passes. After one year candidates are examined in physics, anatomy and physiology, and hospital practice and care of patient. These examinations are taken both by students who intend to become diagnostic radiographers and by those who wish eventually to work in radiotherapy departments. The second part of the examination, taken after a further year, has separate papers for the two groups, dealing appropriately with apparatus and techniques.

The Society of Radiographers has a dual role as the examining body and as the negotiating body for salary purposes. Inevitably its proposal to extend the training period has been judged in relation to each of these responsibilities. A radiographer suggested ${ }^{1}$ that one object of the extension was to achieve parity of salary with physiotherapists, who train for three years. This argument has not been put forward by the Society, but has in any case been demolished by the recent salary award, ${ }^{2}$ which gives virtually identical scales to radiographers and physiotherapists. The Society's most recent suggestion ${ }^{3}$ is that the extra year should be used partly for theoretical instruction and partly for systematic practical training and experience, with limited responsibilities and without salary. The proposal has had a mixed-though broadly favourable-reception among radiographers but has been unambiguously opposed by the Faculty of Radiologists ${ }^{4}$ and individually by many senior radiologists. ${ }^{5-7}$

The feeling that medical auxiliaries are judged and paid not by what they do but by the examinations they have to pass is not confined to radiographers, but is a reflection of the generally unsatisfactory arrangements for fixing salary levels and other conditions of service applying to many groups of people essential in the hospital service. Radiographers claim that the increasing complexity of radiological equipment and technique makes their work more difficult. Some radiologists ${ }^{6}$ dispute this contention, pointing to the rapid advance of automation and emphasizing that the more elaborate investigations are always under the direct control of the radiologist, leaving little to the judgment of the radiographer.

No one disputes the need for well-trained radiographers, but is it possible that the present generation of students are being trained in the wrong things? From the standpoint of the radiologist or the patient does it matter whether the radiographer understands the construction of an autotransformer, the damping of a galvanometer suspension, or the minutiae of photographic chemistry ? Should he know how to treat lymphatic leukaemia ? Does radiography demand such a degree of maturity that aspirants cannot start practising their calling until the age of 20 ? Having now gained satisfactory salary scales for their members, the Society of Radiographers would be widely supported in a realistic study of these requirements and of their influence both on the recruitment of students and on their fitness for the work they will perform.

\footnotetext{
1 Soldinger, R., Brit. med. $\mathcal{F}$, $1964,2,948$.
2 Whitley Council for the Health Services (Great Britain), P.T.A. circular 116 (29 October 1964).

sadiography, 1965, 31, 48.

- Faculty of Radiologists, Annual Report of the Council for 1963-4, para. 18. 1964.

- Jacobs, P., Brit. med. F., 1964, 1, 164 ?

- Eban, R. E., ibid., 1965, 1, 194.

'MacDonald, J. S., et al., ibid., 1965, 1, 455.
} 